\title{
Regulation of Renal Cortex Ammoniagenesis
}

\author{
I. STIMULATION OF RENAL CORTEX AMMONIAGENESIS IN VITRO \\ BY PLASMA ISOLATED FROM ACUTELY ACIDOTIC RATS
}

\author{
George A. O. Alleyne and Anne Roobol \\ From the Department of Medicine, University of the West Indies, \\ Mona, Kingston 7, Jamaica, West Indies
}

\begin{abstract}
A в S TRACT We studied the acute renal metabolic response in rats made acidotic by a single oral dose of ammonium chloride. Cortical slices from acutely (2-h) acidotic rats utilized more glutamine and produced more anmonia and glucose from glutamine than slices from normal animals. When cortical slices from normal rats were pretreated in vitro with plasma isolated from acutely acidotic rats, they achieved similar increases in glutamine utilization, ammonia formation, and gluconeogenesis from glutamine. We did not observe such stimulation in normal cortical slices pretreated in a low $\mathrm{pH}$-low bicarbonate medium. Our data show that a nondialysable factor is present in plasma from acutely acidotic rats that may be responsible for the early increase in the urinary ammonia observed in such animals.
\end{abstract}

\section{INTRODUCTION}

The mechanism whereby the kidney increases ammonia formation in response to acidosis is still unclear, although several proposals have been made that have been critically reviewed recently (1). There is no doubt, however, that after an acid load is given to a rat, there is a rise in urinary ammonia within $1 \mathrm{~h}$ (2). Further, cortical slices, taken from the kidneys of rats given ammonium chloride $2 \mathrm{~h}$ before, show an increase in ammoniagenic capacity (2). In contrast, it has been shown that when renal slices are incubated at an acid $\mathrm{pH}$, no increase in ammonia production can be demonstrated (3). Since comparable degrees of extracellular acidosis can be achieved in vitro as well as in vivo, it seemed likely to us that it was not the actual $\mathrm{pH}$ change that was operative. It seemed to us that the kid-

Dr. Roobol is supported by a grant from the Wellcome Trust, London.

Receiacd for publication 20 Iune 1973 and in revised form 27 August 1973. neys of acidotic rats were conditioned in vivo by some circulatory substance or substances. In order to demonstrate such a factor, it is critical that the acidosis be of short duration to avoid the adaptive enzyme changes that occur in prolonged acidosis $(4,5)$.

The experiments reported here were undertaken to define the factor(s) responsible for the rapid increase in renal ammoniagenesis that occurs after an acid load. We have found that increased ammonia formation can be achieved in vitro by preincubating rat renal cortical slices in plasma isolated from acutely acidotic rats.

\section{METHODS}

Animals and tissue preparation. Adult Sprague-Dawley rats of a locally bred strain (200-300 g body weight) were used. All animals were starved 18-22 $\mathrm{h}$ before experimentation. In any one experiment rats of the same sex were used. Acute metabolic acidosis was induced as described previously (2). When plasma samples were required all animals were injected intraperitoneally with $250 \mathrm{U}$ of heparin. After $5 \mathrm{~min}$ the animals were stunned and killed by decapitation, and the blood was collected. Blood samples were centrifuged at $1,200 \mathrm{~g}$ for $15 \mathrm{~min}$ in a refrigerated MSE 2L centrifuge (Measuring and Scientific Equipment Ltd., Crawley, Sussex, England), and the resulting plasmas kept on ice. Slices of kidney cortex were prepared as described previously (2) from kidneys removed from animals killed by cervical fracture.

Preincubation procedure. Media used for the preincubation were as follows: Krebs bicarbonate buffers containing $75 \mathrm{mg} / 100 \mathrm{ml}$ glucose, $0.51 \mathrm{mM}$ glutamine, with or without $8 \mathrm{~g} / 100 \mathrm{ml}$ bovine serum albumin (BSA) ${ }^{1}$, fraction $\mathrm{V}$ dialysed against the appropriate Krebs bicarbonate buffer overnight at $5^{\circ} \mathrm{C}$; and $25 \mathrm{mM}$ or $10 \mathrm{mM} \mathrm{NaHCO}$ were gassed with $\mathrm{O}_{2}+\mathrm{CO}_{2}(95: 5)$. The resulting $\mathrm{pH}$ 's of these media were approximately 7.4 and 7.0 , respectively, at $37^{\circ} \mathrm{C}$. When the $\mathrm{NaHCO}_{3}$ concentration was reduced to $10 \mathrm{mM}$, an appropriate volume of $\mathrm{NaCl}(0.154 \mathrm{M})$ was added to

\footnotetext{
${ }^{1}$ Abbrcziation used in this paper: BSA, bovine serum albumin.
} 
TABLE I

Ammonia and Glucose Production by Cortex Slices taken from Normal and Acutely (2-h) Acidotic Rats (Substrate 2 mM Glutamine)

\begin{tabular}{cccc}
\hline & $\begin{array}{c}\text { Glutamine } \\
\text { utilized }\end{array}$ & $\begin{array}{c}\text { Net ammonia } \\
\text { formed }\end{array}$ & $\begin{array}{c}\text { Net glucose } \\
\text { formed }\end{array}$ \\
\hline & $\mu m o l / g d r y w t$ & $\mu m o l / g d r y w t$ & $\begin{array}{c}\mu m o l / g d r y w t \\
\text { per } h\end{array}$ \\
per $h$ & per $h$ & $239 \pm 8(27)$ & $29.9 \pm 2.4(17)$ \\
Normal & $241 \pm 8^{*}(12) \ddagger$ & $239 \pm 0.6 \pm(17)$ \\
Acidotic & $306 \pm 11(12)$ & $294 \pm 8(26)$ & $36.6 \pm 1.7(17)$ \\
$P \S$ & $<0.001$ & $<0.001$ & $<0.05$ \\
\hline
\end{tabular}

Incubation medium contained $120 \mathrm{mM} \mathrm{NaCl}, 1 \mathrm{mM} \mathrm{CaCl}$,

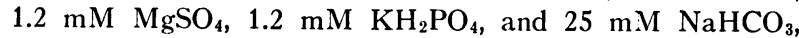
with or without $2 \mathrm{mM}$ glutamine.

* Mean \pm SEM

$\ddagger$ No. of observations

§ Significance of difference from normals.

keep the osmolality the same as in the buffer which contained $25 \mathrm{mM} \mathrm{NaHCO}$.

Plasma samples from normal and acutely acidotic rats were gassed with $\mathrm{O}_{2}+\mathrm{CO}_{2}(95: 5)$ and the resulting $\mathrm{pH}$ values were 7.48 and 7.20 , respectively. A portion of plasma from acidotic rats was titrated with $0.5 \mathrm{M} \mathrm{NaHCO}$ so that the $\mathrm{pH}$ after gassing was 7.48. When stored for $24 \mathrm{~h}$ at $5^{\circ} \mathrm{C}$, plasma samples were gassed with $\mathrm{O}_{2}+\mathrm{CO}_{2}(95: 5)$ and kept in stoppered Erlenmeyer flasks. Samples of plasma were also dialysed against $40 \mathrm{vol}$ of Krebs bicarbonate buffer containing $75 \mathrm{mg} / 100 \mathrm{ml}$ glucose, $0.51 \mathrm{mM}$ glutamine, and $25 \mathrm{mM}$ or $10 \mathrm{mM} \mathrm{NaHCO}_{3}$ for normal and acidotic plasmas, respectively. The dialysis vessel was then gassed with $\mathrm{O}_{2}+\mathrm{CO}_{2}(95: 5)$, stoppered, and kept at $5^{\circ} \mathrm{C}$ for $24 \mathrm{~h}$. The electrolyte concentrations for plasma from four normal rats were (meq/liter $\pm S E M$ ) sodium, $143 \pm 2$; potassium, $4.9 \pm 0.5$; calcium, $5.4 \pm 0.3$; and for four acidotic rats sodium, $142 \pm 2$; potassium, $4.7 \pm 0.2$; and calcium 5.2 \pm 0.4 .

For each preincubation, 8-10 slices of kidney cortex from normal rats were placed in a $100-\mathrm{ml}$ Erlenmeyer flask containing $12 \mathrm{ml}$ of the appropriate medium, which was then gassed with $\mathrm{O}_{2}+\mathrm{CO}_{2}(95: 5)$, stoppered, and incubated for $2 \mathrm{~h}$ at $37^{\circ} \mathrm{C}$ in a metabolic bath that oscillated at 100 cycles/min. After preincubation, the slices were removed from the medium and rinsed twice in $0.9 \% \mathrm{NaCl}$ before transfer to the subsequent incubation.

Incubation procedure. The medium used for incubation was $\mathrm{Krebs}$ bicarbonate buffer containing $25 \mathrm{mM} \mathrm{NaHCO}$ $1 \mathrm{mM} \mathrm{CaCl}$, and $2 \mathrm{mM}$ glutamine, unless otherwise stated. After gassing with $\mathrm{O}_{2}+\mathrm{CO}_{2}(95: 5)$ the $\mathrm{pH}$ of this medium was 7.4 at $37^{\circ} \mathrm{C}$. Each slice (untreated or preincubated as above) was placed in a $50-\mathrm{ml}$ Erlenmeyer flask containing $5 \mathrm{ml}$ of medium, which was then flushed with $\mathrm{O}_{2}+\mathrm{CO}_{2}$ (95:5), stoppered, and incubated for $1 \mathrm{~h}$ at $37^{\circ} \mathrm{C}$ in a metabolic bath that oscillated at $100 \mathrm{cycle} / \mathrm{min}$. After incubation, the slice was removed, placed on a weighed planchette, and dried at $110^{\circ} \mathrm{C}$ for $2 \mathrm{~h} .0 .5 \mathrm{ml}$ of $10 \%$ perchloric acid was added to the medium and, after centrifugation to remove precipitated protein, the supernate was used for determination of ammonia, glucose, and glutamine content. Net glucose or ammonia formation was calculated as the difference in glucose or ammonia content of incubation media with and without substrate.
Assays. Medium glucose was determined by the glucose oxidase method (6). Medium ammonia content was measured by the method of Kaplan (7). Before determination of medium glutamine content, samples were neutralized with $\mathrm{K}_{2} \mathrm{CO}_{3}$ and methyl orange as indicator. Glutamine was determined as glutamate after glutaminase treatment (8). Glutamate was measured spectrophotometrically by $\mathrm{NADH}$ formation in the presence of glutamic dehydrogenase (9). Substrate utilization was calculated as the difference in substrate content of media incubated with and without slices.

Materials. All chemicals were AnalaR grade. Biochemicals and enzymes were purchased from the Sigma Chemical Co., St. Louis, Mo. Pularin heparin injection BP was purchased from Evans Medical Ltd., Speke, Liverpool, U.K. Dialysis tubing from Arthur $\mathrm{H}$. Thomas Co., Philadelphia, $\mathrm{Pa}$., was boiled in two changes of $1 \mathrm{mM}$ EDTA (sodium salt) and rinsed with deionized water before use.

Statistical analysis. All results are reported as mean \pm SEM. The significance of difference between means was determined by Student's $t$ test.

\section{RESULTS}

Untreated slices. Table I shows that cortical slices from acutely acidotic rats produced more ammonia and glucose from glutamine than slices from normal rats. Glutamine utilization by acidotic slices was also increased. There was actually a decrease in ammoniagenesis when cortex slices from normal rats were incubated at $\mathrm{pH} 7.0(10 \mathrm{mM} \mathrm{NaHCO})^{-}-$Table II. Acidosis in vitro enhanced glucose production only in the absence of calcium from the incubation medium (Table II, ref. 10).

Slices preincubated in Krebs bicarbonate buffers. Preincubation for $2 \mathrm{~h}$ did not impair the capacity of cortical slices to form ammonia and glucose from glutamine. The rates of ammoniagenesis for slices preincubated in Krebs bicarbonate buffers were consistently higher than those observed for untreated slices (Table III). A decrease in preincubation medium $\mathrm{pH}$ and bicarbonate concentration did not lead to an increased capacity for ammonia formation from glutamine as shown in Table III. The small decrease observed in ammoniagenesis by such slices was similiar to the decrease in ammonia formation by untreated slices incubated at the lower $\mathrm{pH}$.

Preincubation in the presence of $8 \mathrm{~g} / 100 \mathrm{ml} \mathrm{BSA}$ at $\mathrm{pH} 7.4$ or 7.0 depressed the capacity of slices for ammoniagenesis from glutamine so that the rate of ammonia formation was similar to that of untreated slices from normal rats (Table III).

Slices preincubated in rat plasma. Table IV. Preincubation in plasma from acidotic rats increased the capacity of slices from normal rats to produce ammonia and glucose from glutamine when compared with slices preincubated in the plasma from normal rats. This effect on ammoniagenesis, but not gluconeogenesis, persisted in acidotic plasma adjusted to normal values of $\mathrm{pH}$ and bicarbonate content. Storage at $5^{\circ} \mathrm{C}$ for $24 \mathrm{~h}$ and dialysis did not diminish the ability of acidotic plasma to 
TABLE II

Effect of in vitro Acidosis on Ammonia and Glucose Production by Cortex Slices taken from Normal Rats

\begin{tabular}{|c|c|c|c|c|c|c|}
\hline \multicolumn{4}{|c|}{ Incubation medium $\|$} & \multirow[b]{2}{*}{$\begin{array}{c}\text { Glutamine } \\
\text { utilized }\end{array}$} & \multirow[b]{2}{*}{$\begin{array}{l}\text { Net ammonia } \\
\text { formed }\end{array}$} & \multirow[b]{2}{*}{$\begin{array}{l}\text { Net glucose } \\
\text { formed }\end{array}$} \\
\hline $\begin{array}{l}\text { Glutamine } \\
\text { concn }\end{array}$ & $\mathrm{Ca}^{2+}$ concn & $\begin{array}{l}\mathrm{HCO}_{3-}^{-} \\
\text {concn }\end{array}$ & $\mathrm{pH}$ & & & \\
\hline$m M$ & $m M$ & $m \cdot M$ & & & $\mu m o l / g d r y$ wt per $h$ & \\
\hline 2 & 1 & 25 & 7.4 & $241 \pm 8^{*}(12) \ddagger$ & $239 \pm 8(27)$ & $29.9 \pm 2.4(17)$ \\
\hline 2 & 1 & 10 & 7.0 & $192 \pm 10(12)$ & $212 \pm 9(12)$ & $32.6 \pm 2.9(12)$ \\
\hline $\mathrm{P}$ & & & & $<0.001$ & $<0.05$ & NS \\
\hline 10 & 1 & 25 & 7.4 & - & $602 \pm 30$ & $51.4 \pm 5.6(7)$ \\
\hline 10 & 1 & 10 & 7.0 & - & $551 \pm 29$ & $55.7 \pm 4.6$ \\
\hline$P$ & & & & & NS & NS \\
\hline 10 & 0 & 25 & 7.4 & - & $437 \pm 27$ & $26.2 \pm 2.1$ \\
\hline 10 & 0 & 10 & 7.0 & - & $399 \pm 23$ & $40.0 \pm 2.6(7)$ \\
\hline$P$ & & & & & NS & $<0.005$ \\
\hline
\end{tabular}

$*$ Mean \pm SEM.

$\ddagger$ No. of observations.

$P$, significance of difference from incubation at $\mathrm{pH} 7.4$.

|| Other components of the incubation medium were $120 \mathrm{mM} \mathrm{NaCl}, 4.8 \mathrm{mM} \mathrm{KCl}, 1.2 \mathrm{mM} \mathrm{Mg} \mathrm{SO}{ }_{4}$, and $1.2 \mathrm{~m} \mathrm{M} \mathrm{KH}_{2} \mathrm{PO}_{4}$. When $\mathrm{NaHCO}_{3}$ concentration was reduced to $10 \mathrm{mM}$, an appropriate volume of $\mathrm{NaCl}^{3}$

$(0.154 \mathrm{M})$ was added.

enhance the capacity of normal cortex slices for ammoniagenesis and gluconeogenesis. Increased ammonia formation was associated with increased glutamine utilization by the pretreated slices.

\section{DISCUSSION}

Before considering the significance of our data we would like to justify our use of the preincubation procedure. There are two reasons for use of the method. In previous studies of in vivo metabolic acidosis (2) cortical slices had been taken from normal and acidotic animals $2 \mathrm{~h}$ after an acid load and all slices had then been incubated in the same medium $\left(25 \mathrm{mM} \mathrm{NaHCO}_{3}\right.$, $\mathrm{pH}$ 7.4) for determination of ammonia and gluconeogenesis. For our in vitro study we wished to parallel this earlier procedure as closely as possible, i.e. by placing pretreated cortical tissue samples in the same final incubation medium. The preincubation procedure was also more practical than direct incubation because of the limited amounts of rat plasma available to us. The viability of cortical slices after $2 \mathrm{~h}$ of preincubation appeared satisfactory in that gluconeogenesis and ammoniagenesis were not impaired by this procedure. All preincubation media contained glucose at a normal fasting level in an attempt to minimize energy depletion of the slices during preincubation.

Our data clearly demonstrate that the effect of acute
TABLE III

Effect of Preincubation in Krebs Bicarbonate Buffers of Cortex Slices taken from Normal Rats on

Ammonia and Glucose Production

(Substrate $2 \mathrm{mM}$ Glutamine)

\begin{tabular}{|c|c|c|c|}
\hline $\begin{array}{c}\| \text { Preincubation } \\
\text { medium }\end{array}$ & $\begin{array}{l}\text { Glutamine } \\
\text { utilized }\end{array}$ & $\begin{array}{c}\text { Net } \\
\text { ammonia } \\
\text { formed }\end{array}$ & $\begin{array}{l}\text { Net } \\
\text { glucose } \\
\text { formed }\end{array}$ \\
\hline & $\begin{array}{c}\mu m o l / g \\
d r y \text { wt per } h\end{array}$ & $\begin{array}{c}\mu \mathrm{mol} / \mathrm{g} \\
d r y \text { wt per } h\end{array}$ & $\begin{array}{c}\mu \mathrm{mol} / \mathrm{g} \\
d r y \text { wt per } h\end{array}$ \\
\hline $\begin{array}{c}\text { Krebs bicarbonate } \\
\text { buffer, pH } 7.4\end{array}$ & $310 \pm 20 *(18) \ddagger$ & $300 \pm 8$ & $36.2 \pm 2.1$ \\
\hline $\begin{array}{c}\text { Krebs bicarbonate } \\
\text { buffer, } \mathrm{pH} 7.0\end{array}$ & $292 \pm 28$ & $272 \pm 9(18)$ & $36.0 \pm 1.9$ \\
\hline$P \S$ & NS & $<0.001$ & NS \\
\hline $\begin{array}{l}\text { Krebs bicarbonate } \\
\text { buffer }+8 \mathrm{~g} / 100 \mathrm{~g} \\
\text { BSA, pH } 7.4\end{array}$ & $252 \pm 15(6)$ & $217 \pm 11$ & $37.4 \pm 3.3(6)$ \\
\hline $\begin{array}{l}\text { Krebs bicarbonate } \\
\text { buffer }+8 \mathrm{~g} / 100 \mathrm{~g} \\
\text { BSA, pH } 7.0\end{array}$ & $225 \pm 15$ & $202 \pm 15(6)$ & $30.6 \pm 4.0(6)$ \\
\hline$P \S$ & NS & NS & NS \\
\hline
\end{tabular}

$*$ Mean \pm SEM.

$\ddagger$ No. of observations.

\$Significance of difference from preincubation at $\mathrm{pH} 7.4$.

\| Preincubation medium contained $120 \mathrm{mM} \mathrm{NaCl}, 4.8 \mathrm{mM} \mathrm{KCl}, 2.5 \mathrm{mM}$ $\mathrm{CaCl}_{2}, 1.2 \mathrm{mM} \mathrm{MgSO} 4,1.2 \mathrm{mM} \mathrm{KH}{ }_{2} \mathrm{PO}_{4}, 25 \mathrm{mM}$ (pH 7.4) or $10 \mathrm{mM}$ (pH 7.0) $\mathrm{NaHCO}_{2}, 75 \mathrm{mg} / 100 \mathrm{ml}$ glucose, $0.51 \mathrm{mM}$ glutamine, with or without $8 \mathrm{~g} / 100 \mathrm{~g}$ dialyzed BSA.

If Final incubation medium contained $120 \mathrm{mM} \mathrm{NaCl}, 4.8 \mathrm{mM} \mathrm{KCl}, 1.0$ $\mathrm{mM} \mathrm{CaCl}, 1.2 \mathrm{mM} \mathrm{MgSO} 4,1.2 \mathrm{mM} \mathrm{KH}{ }_{2} \mathrm{PO}_{4}$ and $25 \mathrm{mM} \mathrm{NaHCO}$, with or without $2 \mathrm{mM}$ glutamine.

Regulation of Renal Cortex Ammoniagenesis 
TABLE IV

Effect of Preincubation in Rat Plasma of Cortex Slices from Normal Rats on Ammonia and Glucose Production (Substrate 2 mM Glutamine)

\begin{tabular}{|c|c|c|c|}
\hline Preincubation medium & $\begin{array}{l}\text { Glutamine } \\
\text { utilized }\end{array}$ & $\begin{array}{l}\text { Net ammonia } \\
\text { formed }\end{array}$ & $\begin{array}{l}\text { Net glucose } \\
\text { formed }\end{array}$ \\
\hline & $\begin{array}{l}\mu \mathrm{mol} / \mathrm{g} d r y w t \\
\quad \operatorname{per} h\end{array}$ & $\begin{array}{c}\mu m o l / g d r y \\
\operatorname{per} h\end{array}$ & $\begin{array}{l}\mu m o l / g d r y w t \\
\operatorname{per} h\end{array}$ \\
\hline Plasma from normal rats & $269 \pm 10^{*}(21) \ddagger$ & $258 \pm 8(27)$ & $27.6 \pm 1.5(17)$ \\
\hline $\begin{array}{l}\text { Plasma from acutely } \\
\text { acidotic rats }\end{array}$ & $\begin{array}{r}315 \pm 13(22) \\
P<0.018\end{array}$ & $\begin{array}{c}329 \pm 10(28) \\
P<0.001\end{array}$ & $\begin{array}{c}35.6 \pm 2.0(18) \\
P<0.005\end{array}$ \\
\hline $\begin{array}{l}\text { Plasma from acutely } \\
\text { acidotic rats adjusted } \\
\text { to } \mathrm{pH} 7.48 \text { with } \mathrm{NaHCO}_{3}\end{array}$ & - & $\begin{array}{c}315 \pm 10(12) \\
P<0.005\end{array}$ & $\begin{array}{c}30.2 \pm 2.0(12) \\
\mathrm{NS}, P<0.1\end{array}$ \\
\hline $\begin{array}{l}\text { Plasma from normal rats } \\
\text { stored at } 5^{\circ} \mathrm{C} \text { for } 24 \mathrm{~h}\end{array}$ & - & $213 \pm 8(6)$ & $28.2 \pm 1.3(6)$ \\
\hline $\begin{array}{l}\text { Plasma from acutely acidotic } \\
\text { rats stored at } 5^{\circ} \mathrm{C} \text { for } 24 \mathrm{~h}\end{array}$ & 一 & $\begin{aligned} 262 & \pm 12(6) \\
P & <0.005\end{aligned}$ & $\begin{array}{c}35.2 \pm 1.1(6) \\
P<0.001\end{array}$ \\
\hline $\begin{array}{l}\text { Dialyzed plasma from } \\
\text { normal rats }\end{array}$ & - & $225 \pm 9(6)$ & $28.5 \pm 1.9(6)$ \\
\hline $\begin{array}{l}\text { Dialyzed plasma from acutely } \\
\text { acidotic rats }\end{array}$ & & $\begin{aligned} 267 & \pm 11(6) \\
P & <0.005\end{aligned}$ & $\begin{array}{c}36.1 \pm 2.4(6) \\
P<0.05\end{array}$ \\
\hline
\end{tabular}

Final incubation medium contained $120 \mathrm{mM} \mathrm{NaCl}, 4.8 \mathrm{mM} \mathrm{KCl}, 1 \mathrm{mM} \mathrm{CaCl}, 1.2 \mathrm{mM}$ $\mathrm{MgSO}_{4}, 1.2 \mathrm{mM} \mathrm{KH} \mathrm{mO}_{4}$, and $25 \mathrm{mM} \mathrm{NaHCO}$ with or without $2 \mathrm{mM}$ glutamine.

* Mean \pm SEM.

$\ddagger$ No. of observations.

$\S$ Significance of difference from preincubation in the plasmas from normal rats.

acidosis in vivo on cortical ammonia and glucose production from glutamine can be closely paralleled in vitro by pretreatment of the cortical slice in plasma from acidotic rats. The effect on ammoniagenesis is not related to the decreased $\mathrm{pH}$ or bicarbonate content of acidotic plasma, since the plasma effect persists when these parameters have been restored to normal values. Further, the effect of plasma preincubation cannot be reproduced by preincubation in a Krebs bicarbonate buffer of $\mathrm{pH}$ and bicarbonate content similar to acidotic plasma.

Preincubation in Krebs bicarbonate buffers consistently increased the capacity of the slice for ammoniagenesis above that observed with fresh tissue. The reason for this is not understood. It is also not clear why preincubation in Krebs bicarbonate buffers in the presence of BSA should maintain the capacity of the slice for ammoniagenesis at the level shown by fresh tissue. In this respect pretreatment with BSA had an effect similar to pretreatment with plasma. However, slices did not respond to preincubation at a lowered $\mathrm{pH}$ and bicarbonate concentration in the presence of BSA in a manner comparable with slices pretreated in acidotic plasma.

These data indicate that a specific factor, other than lowered bicarbonate content or $\mathrm{pH}$, is present in acidotic plasma that enhances the capacity of the renal cortex for ammoniagenesis. Preliminary experiments, in which we have pretreated rat cortex slices with human plasma, indicate that the same or a similar factor may also be present in human plasma $2-5 \mathrm{~h}$ after an oral dose of ammonium chloride $(0.1 \mathrm{~g} / \mathrm{kg}$ body $\mathrm{wt})$.

At present we can only speculate as to the mode of action of this plasma factor that increases renal cortex ammonia production. The rapidity of the response by the cortical slices would seem to rule out adaptive changes in de novo protein synthesis of enzyme. In our experiments, increased ammoniagenesis was consistently paralleled by increased glutamine utilization: the ratio of ammonia formed to glutamine utilized was not enhanced by pretreating slices with plasma from acidotic rats. If glutamine uptake is rate-limiting for ammonia formation, then it is possible that the acidotic plasma factor enhances ammoniagenesis by increasing the permeability of the cortical cell membrane towards glutamine. It is unlikely that a change in the permeability of the mitochondrial membrane towards glutamine is involved, since Simpson and Sherrard (11) have shown that cortical slices, but not mitochondria, from chronically acidotic dogs oxidize glutamine more rapidly than those from alkalotic dogs. In the experiments described here, the ratio of ammonia produced to gluta- 
mine utilized approaches unity. Other experiments" show that a large fraction of the glutamine utilized can be accounted for as glutamate appearing in the incubation medium.

As far as we are aware this is the first demonstration that the effects of acute metabolic acidosis on renal cellular processes may be mediated through a circulating plasma factor. The specific nature of this factor and the exact mechanism of action are the subject of current investigation. We suggest that the acute response to an acid load is the release of this circulating factor, which increases the permeability of the cortical cell membrane towards glutamine and that this in turn is responsible for the rapid increase in ammoniagenesis observed. Other changes in the cortical cell associated with acidosis, such as increased gluconeogenic capacity, may be required to sustain this increased ammonia production.

\section{ACKNOWLEDGMENTS}

We thank Miss Sonja Vassall for technical assistance.

\section{REFERENCES}

1. Pitts, R. F. 1972. Control of renal production of ammonia. Kidney Int. $1: 297$.

${ }^{2}$ Roobol, A., and G. A. O. Alleyne. Manuscript in preparation.
2. Alleyne, G. A. O. 1970. Renal metabolic response to acid-base changes. II. The early effects of metabolic acidosis on renal metabolism in the rat. J. Clin. Invest. 49: 943.

3. Pagliara, A. S., and A. D. Goodman. 1970. Relation of renal cortical gluconeogenesis, glutamate and production of ammonia. J. Clin. Invest. 49: 1967.

4. Davies, B. M. A., and J. Yudkin. 1952. Studies in biochemical adaptation. The origin of urinary ammonia as indicated by the effects of chronic acidosis and alkalosis in some renal enzymes in the rat. Biochem. J. 52: 407.

5. Alleyne, G. A. O., and G. H. Scullard. 1969. Renal metabolic response to acid-base changes. I. Enzymatic control of ammoniagenesis in the rat. J. Clin. Invest. 48: 364 .

6. Huggett, A. St. G., and D. A. Nixon. 1957. Use of glucose oxidase, peroxidase and O-dianisidine in determination of blood and urinary glucose. Lancet. II : 368.

7. Kaplan, A. 1965. Urea nitrogen and urinary ammonia. Stand. Methods Clin. Chem. 5: 245.

8. Lund, P. 1970. L-glutamine. In Methoden der Enzymatischen Analyse. H.-U. Bergmeyer, editor. VerlagChemie, Weinheim, Germany. 2nd edition. 1671.

9. Bernt, E., and H.-U. Bergmeyer. 1965. L-glutamate. In Methods of Enzymatic Analysis. H.-U. Bergmeyer, editor. Academic Press, Inc., New York. 384.

10. Alleyne, G. A. O., H. Flores, and A. Roobol. 1973. The interrelationship of acidosis and calcium in the stimulation of renal gluconeogenesis in vitro. Biochem. $J$. In press.

11. Simpson, D. P., and D. J. Sherrard. 1969. Regulation of glutamine metabolism in vitro by bicarbonate ion and pH. J. Clin. Invest. $48: 1088$. 